future professional psychologists in a higher education institution; after testing and refinement, it can be recommended for implementation in the teaching and educational process.

Conclusion. The review of scientific publications on the subject matter allows us to state that the existing works contain only a certain set of disparate data that are difficult to unite into a holistic concept suitable for teaching and understanding by students, which creates certain difficulties both in its teaching and mastering by students. The application of the research approach to elucidating of this subject matter in the course of its teaching student psychologists allows to systematize the existing knowledge, expound it in a certain logical sequence and make it more accessible and understandable, as well as, form a positive motivation for its study and overcome a number of difficulties associated with its development. The introduction to the proposed approach makes it possible to raise the interest in studying of this subject matter among students and interest them in the independent study of other aspects, methods and perspectives of consciousness research, which has a positive impact on their involvement in research activities, as well as on the pro- cess of their professional development in the course of a professional learning.

Annotation. The article attempts to highlight the peculiarities and the course of the application of a rational approach to the study of consciousness research in educational work with student psychologists in the process of studying in higher educational institutions. An overview of scientific publications on the subject matter; The subjects and approaches to the study of consciousness are elucidated. The peculiarities of research of consciousness in psychology at different periods of its formation are highlighted. The specificity of involving students in the study of consciousness, at each of the stages of its study, is considered. The conclusions drawn from the work performed and the prospects of further research in this direction are made.

Keywords: research of consciousness, research approach to the educational process, psychological novel, psychological analysis, introspection, flow of consciousness, educational work with student psychologists.

Одержано редакиією 14.08.2018 Прийнято до публікаиї̈ 19.08.2018

DOI 10.31651/2524-2660-2018-17-19-26

ORCID 0000-0002-0656-2413

DANYLYUK Serhiy,

Doctor in Pedagogy, Professor,

Chair of Higher School Pedagogy and Educational Management Department, Bohdan Khmelnytsky National University at Cherkasy e-mail: sedan@bigmir.net

УДК $378.091 .12: 364-051$ (045)

\title{
USE OF COGNITIVE EDUCATIONAL MODELS IN MANAGEMENT OF ESTABLISHMENTS OF EDUCATION
}

Abstract. Introduction. The development of education informatization entails a variety of forms of representation of real world. The development of information representation forms leads to the creation of new educational models. One of the new educational models are cognitive educational models.

Cognitive technologies are methods and algorithms for achieving the goals of subjects, based on data about the processes of knowledge, training, communication, processing information by humans and animals, on the presentation of neuroscience, on the theory of self-organization, computer information technologies, mathematical modeling of elements of consciousness, a number of other scientific areas, recently related to the field of fundamental science.

Purpose. The aim of the paper is to specify use of cognitive educational models in management of educational establishments.

Results. Such three areas of cognitive models application, as classical education, multimedia and virtual education and testing are singled out. Two mechanisms that are used by the human thinking and cognitive process (cognitiveness) are characterized. One mechanism makes it possible to work with chains of characters with which semantic meanings are related. In this case, the person works with chains, that is, not with integrated in- formation models. Another mechanism of thinking makes it possible to work with images and representations (models) of these images. It is stated that human thinking and behavior are due to mutual work of both hemispheres of the human brain.

Originality. The major pro and contra arguments of use of cognitive educational models in management of educational establishments are revealed in the paper.

Conclusion. Cognitive educational models are formed on the basis of certain principles and they possess a number of properties that distinguish them from informational educational models. They, on the one hand, contribute to the development of creativity in learning. On the other hand, they create an increased load on teacher and require the development of new methods of cognitive testing.

Keywords: education informatization; cognitive educational models; management of educational establishments; classical education; multimedia and virtual education; testing.

The development of education informatization entails a variety of forms of representation of real world. The development of information representation forms leads to the creation of new educational models. One of the new 
educational models are cognitive educational models.

Cognitiveness (Latin cognitio, "cognition, study, awareness") is a property, denoting ability to know. It refers to a human, an animal and artificial system [1].

Cognitive technologies are methods and algorithms for achieving the goals of subjects, based on data about the processes of knowledge, training, communication, processing information by humans and animals, on the presentation of neuroscience, on the theory of selforganization, computer information technologies, mathematical modeling of elements of consciousness, a number of other scientific areas, recently related to the field of fundamental science [2].

As far as education is concerned three areas of cognitive models application can be singled out [3]: 1) classical education; 2) multimedia and virtual education; 3) testing.

Cognitive learning itself was not practiced and was replaced by normative learning. Normative training is based on training standards, rules, principles, which are the same for all the students and do not use cognitive factor. It is due to the fact that it is easy to check the result of such training by comparison and the load on the teacher is much lower. In the process of standard training one task is given to the whole group and the result is checked, but not the method of its production and not creative abilities.

Cognitiveness is closely related to intelligence and creativity. There are no two identical leaves on the tree as well as there are no two people with the same abilities in human society. People are equal in rights as citizens, but not equal in abilities as creative individuals. Therefore, when relying on cognitiveness, inequality of people in mental abilities is revealed. This makes it difficult to find uniform evaluation criterion for such teaching. But the main thing in this case is that the load on the teacher significantly increases. This leads to the need to reduce the study group up to 5-6 people. However, in ordinary education, cognitive methods are still used. They are presented in the form of cognitive graphics.

Before considering cognitive graphics and cognitive models, it is necessary to focus on the features of human thinking.
The human thinking and cognitive process (cognitiveness) use two mechanisms. One mechanism makes it possible to work with chains of characters with which semantic meanings are related. Such thinking is called logical, symbolic or algebraic. In this case, the person works with chains, that is, not with integrated information models.

Another mechanism of thinking makes it possible to work with images and representations (models) of these images. Images have more integrity than symbolic representations. In this case, the person works with integrated information models. With this approach, he recycles much more informative information than in the analysis of characters.

The ability to work with images (with visual images) determines another type of thinking, which is called image, less often geometric image thinking.

Logical thinking is associated with the left hemisphere of the human brain, and figurative thinking is associated with the right hemisphere. Each of the hemispheres of the human brain is an independent information system of perception of the external world and processing information.

Natural language speech, thinking with words, rational-logical procedures of information processing are implemented in the left hemisphere. Problem solving in it is based on the stereotypical approach. In the right hemisphere, thinking at the level of associations and images is realized: aesthetic perception, painting, associative recognition. Problem solving in it is based on a creative approach, which leads to the birth of fundamentally new ideas. Sometimes this mechanism is designated by the term "intuition" that is not correct in many cases. Intuition is often implemented as a form of implicit knowledge [4] and it is not always associated with the right hemisphere form of thinking.

In general, human thinking and behavior are due to mutual work of both hemispheres of the human brain. In some situations the logical component of thinking prevails, in other situations the figurative one prevails. Psychologists divide people into three groups: a) with the prevailing left hemisphere; b) with the right hemisphere; c) with mixed thinking. This separation is genetically predetermined 
and there are special tests for finding out the propensity for one or another type of thinking.

Experiments show that the ability to move from one form of thinking to the other forms a cognitive resource which is the source of a person's creative abilities. Relations and transformations that may be implicit in one form of representation, after the change of representation become apparent and lead to a quick solution of the problem.

The emergence and development of computer graphics have created a fundamentally new cognitive learning opportunities [5]. Students can dynam?cally manage the content, shape, size and color of the image in the learning process. The use of graphics in educational computer systems increases the speed of information transmission to students and increases the level of its understanding. Computer graphics impact on figurative thinking led to the emergence of new learning technologies and new information models. Such graphics, which performs not only the functions of information (image) transferring, but also cognitive functions are called cognitive.

Cognitive graphics in the broadest sense of the word is a polysemantic concept. It is interpreted in different ways, depending on the application [1]:

1) (AI) as a set of techniques and methods for figurative presentation of conditions of the task, which allows either to immediately see the solution, or to get a hint for this finding;

2) (training) as a set of techniques and methods of figurative knowledge transfer;

3) (modeling) as a set of techniques and methods of figurative problem solving;

4) (management) as the direction in the business graphics that links views appearing on the display screen with management processes. Cognitive graphics allows to visualize the decision making process.

With a well-thought-out visualization system, images that arise in the dynamics on the screen can help the decision maker in the interactive mode to see those patterns or solutions of a problem that were not previously available for him. Cognitive graphics primarily performs semantic and linguistic functions, that is transfer of content with minimal graphic display devices [1]

There are two functions of computer graphics: 1) illustrative; 2) cognitive. Illustrative function confirms knowledge. Cognitive function helps to get new knowledge. Summarizing, we can say that in the process of usual, normative learning cognitive graphics performs functions of knowledge transfer support by a teacher or passive functions.

In multimedia and virtual education, cognitive graphics performs active functions, because it affects the student directly, bypassing teacher [6]. "Virtual education" includes such components as: a) virtual information field [7]; b) virtual educational space, virtual educational models, information models of the situation [8]; c) information interaction [9]; d) the language of information virtual interaction. These components determine the interaction of subjects of interaction in the field of education. Components of virtual models in education in the information aspect are:

- informational situation models;

- informational position models;

- dynamic informational models of large informational capacity;

- three-dimensional spatial models;

- intensified multimedia streams;

- new user interfaces.

One can make a small comparison of game virtual models and educational virtual models.

Game virtual models are aimed at achieving the end of the game and receiving positive emotions in the "pleasure center" of the player. They include a variety of scenes, the dynamics of images and situations. They include the minimum of audio signals (mainly emotional coloring) and the maximum of visual images that have an associative effect on the player, which creates an "illusion of actions freedom". These models cause great motivation and may even cause a "game need". The main motivation for operating with such models is "getting pleasure".

Educational virtual models are aimed at obtaining knowledge and student competencies. They also include a variety of scenes, dynamics of images and 
situations. However, they are more regulated and limit the student's actions by the area of truth of the right decisions. They include a significant amount of textual information and visual images that have an associative effect on a student, but operations with these images take place in terms of learning tasks solving and full "actions freedom" is missing. These models are less motivated than game virtual models and are aimed at satisfying the "informational needs" and at the elimination of information asymmetry [10]. The main motive of operating with such models is obtaining knowledge and competencies for survival in real world.

Considering the properties of virtual models, it can be noted that many of their properties are related to a person's cognitive area, while others are relatively independent of it.

The basis of virtual models is various information models: information situation and information position of the subject or object managed by him in the information situation.

Among the properties of information models (and virtual ones built on their basis), used to create a virtual space, there are: visibility; perceptibility; target certainty; situational certainty; functionality; completeness; informational conformity; relevance; accuracy; regul?tion; associativity; consistency; reliability $[6,11]$.

Visibility is a property of models, consisting in the fact that a person (within his human intelligence) is able to review the totality of parameters and relat?onships, included in the model and understand this model as a whole. This property in virtual models is significantly higher than in real objects. It is due to the possibility of scaling visual space. For example, a person being in a city sees only the houses around it. But using an electronic map, a navigator, a space snapshot he increases visibility and sees what he cannot see in reality. Accordingly, his decision is more reasonable.

Perceptibility is a property of models that consists in the fact that a person (within his human intelligence) is able to perceive and understand this model as reflection of objective reality or its practical purpose [12]. Perceptibility is associated with the presence of basic knowledge. The more basic knowledge is, the higher perceptibility is.

If the model is boundless or not perceptible, it is usually rejected and not applied by a person. If the model is percived by one person and not perceived by another person, there is a state of information asymmetry between them. The presence of information asymmetry [10] between managers and executives leads to the situation when managers more often reject a new idea, a suggestion or a model which they do not understand.

The goal certainty is in the fact that the model can be used to achieve goals that are understandable and acceptable to a person. The goal certainty of an information model is associated with a game or learning strategy. The goal certainty does not exclude the presence of several goals [13].

The situational certainty is in the fact that the information situation model is determined and creates conditions for actions in this situation to the player or the student. The situational certainty of the information model is associated with operational actions. The subject can act in situations that are understandable for him and are analyzed by him.

Functionality is an a priori property of information models, consisting in the fact that this model can perform a number of functions that are defined and specified in advance.

Completeness is a property of information models that characterizes their sufficiency to make decisions or achieve goals.

Reliability is a property of information models that characterizes their ability to correctly and adequately reflect the objective (based on criteria chosen by a person) reality.

Relevance is a property of the parameters of information models and the entire model in generally to meet (based on criteria chosen by a person) current parameters values and model itself. Relevance implies a certain threshold of the model obsolescence.

Accuracy is the property of information models and their parameters to meet (based on criteria chosen by a person) a 
certain degree of proximity to real state of the object or process of modeling.

Consistency is the property of models to match other similar models and their functions, without disturbing the holistic (in a person's opinion) picture of the world.

Informational correspondence is a property of interacting informational models and their elements, which determines the sufficiency of information resources for performance by models or their elements their functions [14] and implementation of information interaction.

Reliability is a property of information models (in a person's opinion or according to the criterion set by him), reflecting the possibility of obtaining a correct result with the help of use of this model when there are external disturbing effects on the model or changes (within boundaries set by a human) of its parameters.

Regulation is the property of information models to comply certain rules, classifications, syntax, forms of description and representation. This property serves as the basis for the perception of the visual model by the subject and the correct correlating of a virtual image with a real image.

Associativity is the property of information models to cause associations in cognitive area and on the one hand, to create freedom of choice, and on the other hand, to develop creative beginnings in the subject working with such a model.

The underlined properties are relatively independent. All the other properties are associated with a person's cognitive field. The listed basic properties of models are used in information systems and technologies (including education) and determine the so-called information approach.

Italicized fragments of property descriptions reflecting the relationship with cognitive area are usually omitted in the technical description of models and situations. However, they set a certain convention, both when creating models, and when being applied. This convention of models depends on human intelligence and criteria applied by a person.

The expression "in a person's opinion" can be replaced by a more precise term "level of human intelligence" or "level of intelligence". Human intelligence level is significantly different for different people, for example, for specialists in this area and non-specialists. Hence, such properties as visibility and perceptibility are different for different people in particular for decision makers and professionals creating new and complex models.

It should be emphasized that the visibility and perceptibility of virtual models are higher than real world models. This creates a certain comfort. The regulation of virtual models makes the virtual information situation more predictable in comparison with the actual situation. It also creates the feeling of comfort.

From the standpoint of the qualitative content and semantics of information and virtual models they are divided into three categories [15]: 1) descriptive; 2) resource (accumulation of experience); 3) intellectual (active). Descriptive and resource models are enough described [5]. Let us dwell on intellectual [16] ones. Intellectual information models possess a number of properties, among which one should highlight:

Autonomy, that is the models function without the direct intervention of the subject and have the ability to control their actions and internal state.

Communicativeness, that is models interact with other models by means of some communication language.

Reactivity, that is models respond to environmental changes in certain time frames.

Individuality, that is each model has its own picture of the surrounding world, on the basis of which it carries out actions.

Sociability and cooperativity, that is models can exchange information with their environment and other models.

Self-organization, that is model behavior includes the ability to selforganize or to construct a model of the environment in order to find new ways of behavior.

Thus, intellectual models, by virtue of autonomy, create a certain discomfort for the "player".

Each of the many decision steps in a game situation affects the "pleasure center" and increases this feeling in case of a large 
number of steps. Virtual games are based namely on this principle. Achieving the goal is broken into simple stereotypical stages (for example, "shooters") and from a variety of stages comfort is summed.

In educational virtual models, the stages are more complicated. Their number is small and in total the comfort feeling is lower.

When testing, cognitiveness and cognitive models can also be included in testing process. Evaluation of learning outcomes is divided into: a) passive; b) semi-active; 3) active [19].

Passive assessment is based on observation and information gathering. It allows to assess the student's condition (the degree of preparedness), to assess the change of this state (preparedness) at sufficiently long time intervals. This testing has no cognitive models. Such a model and assessment allow identify the state and long-term trends of the process of teaching the personality and mastering knowledge.

The semi-active model is characterized by a one-time impact on the learner and result analysis. Most often, according to this scheme, "question-answer systems" of testing are built. They are a collection of elementary cycles.

In semi-active testing, not the state and trend, but the result of the information impact on the student and his reaction to this impact are assessed. The result of the implementation and the dynamics of the development of these results are evaluated. In this testing cognitive abilities play a dominant role. Therefore, such testing includes cognitive independent models.

In case of active testing, there is a long-term informational interaction [12] between the teacher and the student. Testing activity is in the student's active long-term and adaptive response to the teacher's information impact (test). Such testing includes cognitive integrated models or a linked chain of cognitive models, for example. increasing compl?xity.

At the same time, two qualitatively different types of tests are possible: 1) action tests (AT); 2) situational tests (ST). Action tests are relatively simple, structured procedures orienting the subject to use combinations of stere?typical methods. Situational tests are based on the creation of a situation information model [9] and conducting information interaction in framework of this model in a situation close to reality.

In this testing, not only the result is important, but also the information resource (experience), which the student forms in himself on the basis of solving original and modified tasks.

Active testing reveals the degree of mobility and efficiency of thinking in critical situations and the ability for operational analysis.

All the three approaches complement each other and provide a comprehensive assessment of a trainee's opportunities. The complex of the examined tests allows the formation of multi-level testing framework for comprehensive assessment of learning results. Cognitive models play an important role in such testing systems.

Thus, cognitive educational models are formed on the basis of certain principles and they possess a number of properties that distinguish them from informational educational models. They, on the one hand, contribute to the development of creativity in learning. On the other hand, they create an increased load on teacher and require the development of new methods of cognitive testing.

\section{References}

1. Kudzh, S.A., Solovyov, I.V., Tsvetkov, V.Ya. (2014). Cognitive Models and Methods. Brief dictionaryreference book. MSTU MIREA. $95 \mathrm{p}$

2. Malinetsky, G.G., Manenkov, S.K., Mitin, N.A., Shishov, V.V. (2010). Cognitive challenge and Information Technologies. Preprint. M.V. Keldysh IPM. 46.

3. Ozherelyeva, T.A. (2013). Cognitive features of obtaining the second higher education. Perspectives of science and education. 3. 106-111.

4. Kimble, C. (2013). Knowledge management, codification and tacit knowledge. Information Research. 18(2). paper 577

5. Polyakov, A.A., Tsvetkov, V. Ya. (2008). Applied Informatics: educational and methodical benefit: In 2 parts: Part 1. Moscow: MAKS Press. 788 p.

6. Tsvetkov, V.Ya. (2013). Cognitive aspects of constructing virtual educational models. Prospects of science and education. №3. 38-46.

7. Ivannikov, A.D., Kulagin, V.P., Mordvinov, V.A. and others. (2008). Obtaining knowledge for formation of informational educational resources. Moscow: FGU GNIIA ITT "Informika". 440 p.

8. Tsvetkov, V.Ya. (2012). Information situation and information position as a management tool. European Researcher. Vol. 36. 12-1. 2166-2170.

9. Tsvetkov, V.Ya. (2013). Information interaction as a mechanism of semantic gap elimination. European Researcher. Vol. 45. 4-1. 782-786.

10. Obolyayeva, N.M. (2012). Removing information asymmetry as a tool of improving the quality of education. Geodesy and aerial photography. 6. 123-124. 
11. Tsvetkov, V. Ya. (2013). Spatial information models. European Researcher. Vol. 60. 10-1. 2386-2392.

12. Tsvetkov, V.Ya. (2012). Information management. LAP LAMBERT Academic Publishing GmbH \& Co. KG, Saarbrücken, Germany. 201 p.

13. Tsvetkov, V. Ya. (2012). Multipurpose management. European Journal of Economic Studies. Vol. 2. 2. 140-143.

14. Tikhonov, A.N., Ivannikov, A.D., Solovyov, I.V., Tsvetkov, V. Ya., Kudzh, S.A. (2010). The concept of network-centric management of complex organizational and technical system. Moscow: MaxPress. 136 p.

15. Tsvetkov, V.Ya. (2005). Information model as the basis of information processing in GIS. News of higher educational establishments. Geodesy and aerial photography. 2. 118-122.

16. Tsvetkov, V. Ya. (2013). Spatial knowledge: Formation and presentation. LAP LAMBERT Academic Publishing GmbH \& Co. KG, Saarbrücken, Germany. $107 \mathrm{p}$

17. Kudzh, S.A., Solovyov, I.V, Tsvetkov, V.Ya. (22013). Convergence as an educational category. Remote and virtual learning. 11.10-15.

18. Tsvetkov, V.Ya. (2012). Logics in science and methods of proof. LAP LAMBERT Academic Publishing GmbH \& Co. KG, Saarbrücken, Germany. 84 p.

19. Kulagin, V.P., Tsvetkov, V.Y. (2013). Features of multilevel testing. Remote and virtual training. 4. 512.

\section{Cписок бібціографічних посицань}

1. Кудж С. А., Соловьёв И.В., Цветков В.Я. Когнитивные модели и методы. Краткий словарьсправочник. Москва: МГТУ МИРЭА, 2014. 95 с.

2. Малинецкий Г.Г., Маненков С.К, Митин Н.А, Шишов В.В. Когнитивный вызов и информационные технологии Препринт. ИПМ им. М.В. Келдыша. № 46. 2010.

3. Ожерельева Т.А. Когнитивные особенности получения второго высшего образования. Перспективы науки и образования. 2013. №3. С. 106-111.

4. Kimble, C. (2013). Knowledge management, codification and tacit knowledge Information Research, 18(2) paper 577.

5. Поляков А. А., Цветков В. Я. Прикладная информатика: Учебно-методическое пособие: В 2-х частях. Ч. 1. Москва: МАКС Пресс, 2008. 788 с.
6. Цветков В. Я. Когнитивные аспекты построения виртуальных образовательных моделей. Перспективы науки и образования. 2013. №3. С. 38-46.

7. Иванников А.Д., Кумагин В.П., Мордвинов В.А, и др. Получение знаний для формирования информационных образовательных ресурсов. - М.: ФГУ ГНИИ ИТТ "Информика", 2008. 440с.

8. Tsvetkov V. Ya. Information Situation and Information Position as a Management Tool. European Researcher. 2012. Vol. 36. No 12-1. P. 2166-2170

9. Tsvetkov V. Ya. Information Interaction as a Mechanism of Semantic Gap Elimination. European Researcher. 2013. Vol. 45. No 4-1. P. 782-786.

10. Оболяева Н. М. Устранение информационной асимметрии как инструмент повышения качества образования. Геодезия и аэрофотосъемка. 2012. №6. C. $123-124$.

11. Tsvetkov V.Ya. Spatial Information Models. European Researcher. $2013 . \quad$ Vol. 60. No 10-1. P. 2386- 2392.

12. Цветков В.Я. Информационное управление. LAP LAMBERT Academic Publishing GmbH \& Co. KG, Saarbrücken, Germany, 2012. 201 c.

13. Tsvetkov V.Ya. Multipurpose Management. European Journal of Economic Studies. 2012. Vol. 2. No 2. P. $140-143$.

14. Тихонов А.Н., Иванников А.Д., Соловьёв И.В., Цветков В.Я., Кудж С.А. Концепция сетецентрического управления сложной организационно-технической системой. Москва: МаксПресс, 2010. 136 с.

15. Цветков В.Я. Информационная модель как основа обработки информации в ГИС. Известия высших учебных заведений. Геодезия и аэрофотосъемка. 2005. №2. C. 118-122.

16. Цветков В.Я. Пространственные знания: Формирование и представление. LAP LAMBERT Academic Publishing GmbH \& Co. KG, Saarbrücken, Germany, 2013. 107 c.

17. Кудж С.А., Соловьев И.В., Цветков В.Я. Сходимость как образовательная категория. Дистаниионное и виртуальное обучение. №11. 2013. С. 10-15.

18. Цветков В.Я. Аогика в науке и методы доказательств. LAP LAMBERT Academic Publishing $\mathrm{GmbH}$ \& Co. KG, Saarbrücken, Germany, 2012. 84 c.

19. Кумагин В.П., Цветков В.Я Особенности многоуровневого тестирования. Дистаниионное и виртуальное обучение. 2013. №4. С. 5-12.

\section{ДАниАЮК Сергій Семенович,}

доктор педагогічних наук, професор, завідувач кафедри педагогіки вищої школи і освітнього менеджменту

Черкаського національного університету імені Богдана Хмельницького e-mail: sedan@bigmir.net

\section{ВИКОРИСТАННЯ КОГНІТИВНИХ НАВЧААЬНИХ МОДЕАЕЙ В УПРАВАІННІ ЗАКААДАМИ ОСВІТИ}

Анотаиія. Вступ. Розвиток інформатизаиї освіти тягне за собою різноманітність форм репрезентаиії реального світу. Розвиток форм інформаиійного представлення призводить до створення нових освітніх моделей. Однією з нових освітніх моделей $\epsilon$ когнітивні освітні моделі.

Когнітивні технологї - ие методи та алгоритми досягнення иілей предметів, які базуються на даних про прочеси пізнання, навчання, спілкування, обробки інформації людьми та тваринами, про презентацію нейронауки, про теорію самоорганізаиї, комп'ютерні інформаиійні технології. , математичне моделювання елементів свідомості, ряд інших наукових областей, нешодавно пов'язаних з областю фундаментальної науки.

Мета. Метою статті є уточнення використання когнітивних освітніх моделей в управлінні навчальними закладами.
Результати. Виділяються такі три області за стосування когнітивних моделей, як класична освіта, мультимедіа та віртуальна освіта та тестування. Охарактеризовано два механізми, які використовуються людським мисленням і когнітивним проиесом (когнітивність). Один механізм дозволяе праџювати з ланиюжками символів, з якими пов'язані смислові значення. У иьому випадку людина працюе з ланиюжками, тобто не з інтегрованими інформаиійними моделями. Інший механізм мислення дає можливість праиювати з зображеннями та зображеннями (моделями) иих образів. Встановлено, шо людське мислення і поведінка обумовлені спільною роботою обох півкуль людського мозку.

Оригінальність. У статті висвітлено основні про і протилежні аргументи використання когнітивних освітніх моделей в управлінні навчальними закладами. 
Висновок. Когнітивні освітні моделі формуються на основі певних приниипів $i$ мають ряд властивостей, шо відрізняють ӥх від інфрормаиійних освітніх моделей. Вони, з одного боку, сприяють розвитку творчості в навчанні. 3 іншого боку, вони створюють підвищену навантаження на вчителя $i$ вимагають розробки нових методів когнітивного тестування.
Ключові слова: інформатизаиія освіти; когнітивні освітні моделі; управління навчальними закладами; класична освіта; мультимедіа та віртуальна освіта; тестування.

Одержано редакиією 04.09.2018 Прийнято до публікаиї 19.09.2018

DOI 10.31651/2524-2660-2018-17-26-32

ORCID 0000-0003-3214-7675

\section{ДЕСяТОВ Тимофій Михаймович,}

доктор педагогічних наук, професор,

директор Навчально-наукового інституту педагогічної освіти, соціальної роботи і мистецтва, Черкаський національний університет імені Богдана Хмельницького e-mail: desyatov50@ukr.net

\section{АДАПТАЦІЯ МЕХАНІЗМІВ УПРАВАІННЯ ЯКІСТЮ ПЕДАГОГІЧНОЇ ОСВІТИ УКРАЇНИ ДО МІКНАРОДНИХ СТАНДАРТІВ}

У статті зазначено, шо прочес створення Європейсъкого простору вищої освіти наочно показав необхідність кониентраиії уваги на проблемі забезпечення $i$ покрашення якості як одному з ключових завдань. Доведено, шо сучасна європейсъка практика передбачає розвиток культури якості шияхом впровадження менеджменту якості. Акиентовано увагу на те, шо основними інструментами визначення якості виступають оиінювання внутрішне та зовнішне. Досліджено, шоо складність створення механізмів управління якістю полягає не лише в тому, иоб скоординувати розробку кониепиії на всіх рівнях державного управління, а й у тому, шоб узгодити погляди різних державних відомств. Виділено кілька аспектів, шо є особливо важливими при здійсненні реформ управління якістю. Доведено про необхідність адаптаиії людини до нових умов ї життя та робоmи, а з іншого боку, відбувається адаптаиія самої освіти до життя конкретних людей. Проаналізовано характерні риси освітньої системи України, приниипи, яким повинна відповідати система менеджменту якості освіти в Україні. Наголошено про необхідність участі стейкхолдерів у системі менеджменту якості вищої педагогічної освіти.

Ключові слова: адаптаиія; якість; міжнародні стандарти; механізми управління; менеджмент; акредитаиія; результат; стейкхолдери; приниипи; соиіальні партнери.

Постановка пробцеми. Цілеспрямоване входження України у світову спільноту вимагає проведення всебічного аналізу провідних напрямів еволюції сучасної освітньої практики. Забезпечення високої якості освіти $є$ одним із кАючових принципів та наріжним каменем побудови Європейського простору вищої освіти. На Конференції міністрів, яка відбулася в травні 2018 року в Парижі, очільники європейської освіти ще раз підтвердили важливість цього завдання, а також зобов'язалися "підтримувати подальший розвиток системи забезпечення якості освітнього процесу". На сьогодні українська система педагогічної освіти, на жаль, не є серед країн-лідерів щодо належного забезпечення якості освітнього процесу. У зв'язку з цим спостереження та аналіз оцінки європейських досягнень щодо забезпечення якості на інституційному, національному та континентальному рівнях без сумніву $\epsilon$ цінним для українських науковопедагогічних працівників, що і стало предметом нашого дослідження.

Аналіз останніх досліджень $i$ публікацій. Проблема забезпечення якості освіти на основні стандартів і рекомендацій щодо забезпечення якості в Європейському просторі вищої освіти (ESG) $є$ предметом наукового пошуку вітчизняних й зарубіжних науковців (H. Авшенюк, А. Сбруєва, С. Домбровська, А. Чміль, М. Коровкин, Т. Фініков, А. Васильєв, В. Юскаєв, О. Криклій, О. Міхеєва, С. Курбатов, І. Мусієнко, С. Сисоєва). У зарубіжній педагогіці проблеми забезпечення якості освіти досліджуються у працях таких учених як А. Шиейхер, €. Возніцкі, P. Bennet, K. Gürüz, M. Cheng, L. Matei, Hans Döbert, Lutz R. та ін.. У роботах цих учених висвітлено досвід забезпечення якості в європейському просторі вищої освіти.

Мета статті полягає у висвітленні аналізу та використанні європейського досвіду забезпечення якості освіти в українській системі вищої освіти. 